http://www.jfas.info

\title{
THE STUDY OF EXCHANGE RATES BEHAVIOR IN MALAYSIA BY USING NATREX MODEL
}

\author{
J. M. Shukri ${ }^{1,2, *}$, M. S. Habibullah ${ }^{2}$, Z. Yusop ${ }^{2}$ and L. Chin ${ }^{2}$ \\ ${ }^{1}$ Faculty of Business Management, Universiti Technologi MARA, 23000 Dungun, \\ Terengganu, Malaysia \\ ${ }^{2}$ Faculty of Economics and Management, Universiti Putra Malaysia, 43400 Serdang, Selangor, \\ Malaysia
}

Published online: 10 September 2017

\begin{abstract}
This paper aims to estimate equilibrium exchange rates and identify the determinants of macroeconomics fundamentals affecting exchange rates in Malaysia. By using Natural Real Exchange Rates (NATREX) model, this study adopts the Autoregressive Distributed Lag (ARDL) model to examine the long run relationships (or cointegration) among variables and the dynamic effect within variables in the short run for the period 1970 to 2012 . The results suggest that the terms of trade, dependency ratio of the young, and foreign direct investment play an important role in influencing the exchange rates movement in Malaysia. The result also reveals that the misalignment of exchange rates is quite small and stable in Malaysia during 1983 to 2012, except in 1995.
\end{abstract}

Keywords: natural real exchange rates; exchange rates misalignment; bound testing; ARDL.

\footnotetext{
Author Correspondence, e-mail: mohdshukri@tganu.uitm.edu.my doi: http://dx.doi.org/10.4314/jfas.v9i3s.55
} 


\section{INTRODUCTION}

Malaysia is experiencing rapid economic growth especially during the late 20th century through trade liberalization. The rate of economic growth in Malaysia is growing at the average of $6.5 \%$ annually from 1957 to 2005 . In 2012, the gross domestic product (GDP PPP) was recorded at USD671.8 billion and the rate of economic growth was 5.6\%. The international trade plays an important role in the Malaysian economy and manufacturing sector has contributed for over $40 \%$ of the GDP. Furthermore, the establishment of the Association of Southeast Asian Nations (henceforth ASEAN) since 1967 enhanced international trade among ASEAN members as well as the trade to the rest of the world, thereby involving high transaction of the foreign currency. Malaysia is also experiencing the same impact as this country is a member of ASEAN. Fig. clearly indicates that the trend of exports and imports of goods and services in Malaysia has increased tremendously from 1980 until 2011.

However, this phenomenon (the enhancement of international trade) does not really indicate a good economic performance as a whole for Malaysia. According to [3], a high volatility of exchange rates by small open economy country such as Malaysia especially that rely on international trade may cause national currency to be easily coaxed into undervaluation or overvaluation trap. Generally, the appreciations of domestic currency imply the increasing in competitiveness of the national currency in the currency markets. However, it does not imply increases in competitiveness if high appreciation causes the domestic currency to be overvalued.

Besides that, the internal financial systems in Malaysia are still weak and less resilient, which had only worsened the situation. Thus, with a small open economy and newly industrialized market economies, the Malaysian currency is readily confronted with volatility and misalignment against foreign currencies such as the US dollar. The exchange rate misalignment will occur when there are deviations from its equilibrium path, thus creating opportunities for arbitrage activities. 


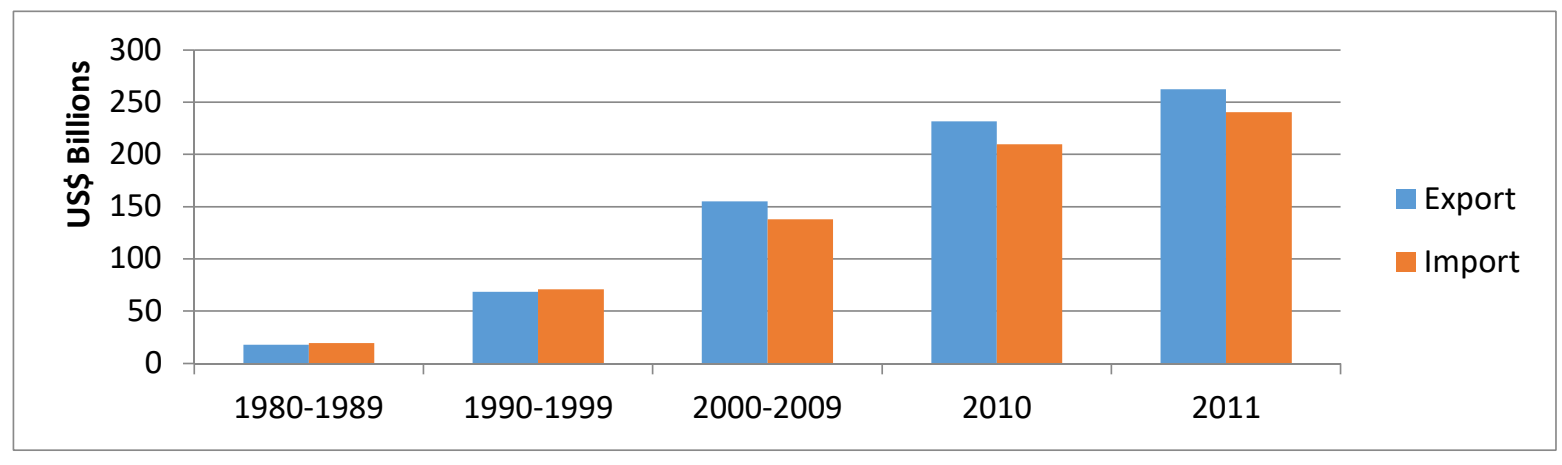

Fig.1. Export and import of goods and services in Malaysia, 1980-2011 (in average)(Source: United Nation Statistic Department (UNSD))

Another issue of concern is the Asian financial crisis 1997 that started in Thailand, which had affected and inhibited the economic growth and development in Malaysia. The crisis also has led to a currency crisis in Malaysia forcing her policy makers back then, to switch the exchange rate regime to fixed exchange rates. However, in [1-2] show that there is little evidence of exchange rate misalignment found in Malaysia including Indonesia, Philippines, Singapore and Thailand during the crisis. Meanwhile, in [13] suggest that exchange rate misalignment and volatility are important determinants in encouraging Malaysia's import flows especially during the 1997 Asian financial crisis. Why some countries should take concern to the exchange rates misalignment? How to assess the equilibrium exchange rate thereby its misalignment?

Firstly, according to [4], the effects of misalignment of currency to a country's economy are quite huge. For instance, the overvaluation of the currency is believed to have caused the national currency to experience depreciation and therefore reduced its economic growth. On the other spectrum, the undervaluation of the currency implies that the national currency tend to appreciate thus making the currency expensive against foreign currency. This usually increase imports and decrease exports demand, thus creating deficit in trade balance. However, in [15] provides evidence that undervaluation of the currency (a high real exchange rate) stimulates economic growth. Meanwhile, according to [19], the persistent exchange rate misalignments are able to generate severe macroeconomic disequilibrium often leading to costly external imbalances and sometimes can be considered as an indicator of potential crisis. Secondly, the traditional theory to study the misalignment of exchange rates was introduced 
by Gustaz Cassel in 1918 through the Purchasing Power Parity (PPP) and the Law of One Price (LOP) theories. The PPP/LOP models used the price based estimates and are relatively easy to implement. However, previous studies argued that these theories are not perfect as it only provides the behavior of exchange rate in the long-run and fail to predict well especially in the short-run. Furthermore, the PPP/LOP theories does not address the economically interesting question of whether a particular exchange rate is driven by economics fundamental. In other word, this concept does not address all factors which may account for deviations from PPP levels in terms of a time-varying equilibrium path of the exchange rate. Fig. describes the theory of PPP and LOP, and the misalignment of exchange rate in Malaysia.

In the case of Malaysia, the study on exchange misalignments is still lacking. For instance, the study conducted by [1-2] explain the exchange rates behavior using the monetary model. Both of these studies estimate exchange rates movement using relative foreign and domestic monetary aggregate, income differential, interest rate differential and expected inflation differential as regressors. However, the models in these studies exclude other macroeconomic fundamental factors which are also important determinants of the exchange rate.

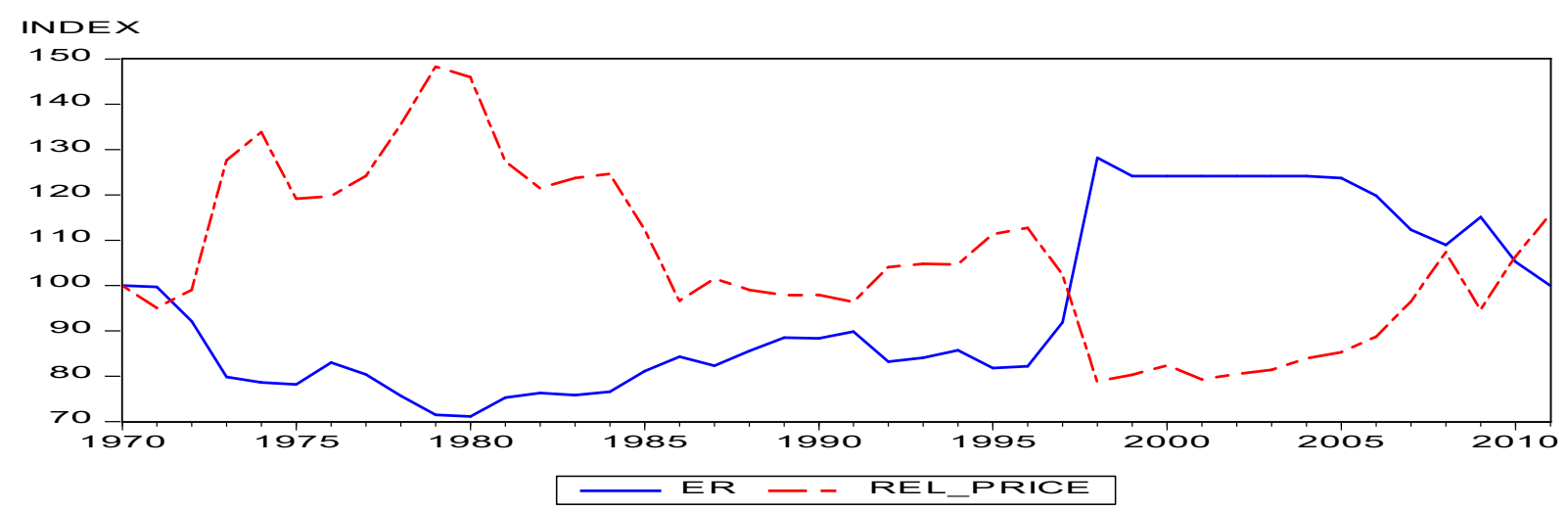

Fig.2. Purchasing power parity, Malaysia/United States, 1970-2012 (Source: World

Development Indicator (WDI), United Nation Statistical Division (2012) and authors' computations. Note: Index $1970=100)$

Besides that, the study conducted by [13] using NATREX model highlights that the real economic fundamentals are government consumption, real interest rate, terms of trade and productivity index. However, according to [20], the social time preference such as the dependency ratio of the young (DEPY) should also be included in the model. Other important fundamental factors that should be considered are the tax revenue and foreign direct 
investment. Fig. clearly indicates that there are downward trends (correlation) in all macroeconomics fundamental variables except real interest rate.

Therefore, the purpose of this paper is to estimate the equilibrium exchange rates using NATREX model and identify the macroeconomic fundamentals as determinants of the exchange rate for Malaysia. Based on our best knowledge, this is the first time that the dependency ratio of the young, tax revenue and foreign direct investment were included as the macroeconomics fundamental factors in examining equilibrium exchange rates for a country. This paper adopted the autoregressive distributed lag (ARDL) model approach to examine long run relationships (or cointegration) among variables and the dynamic effect within variables in the short run.
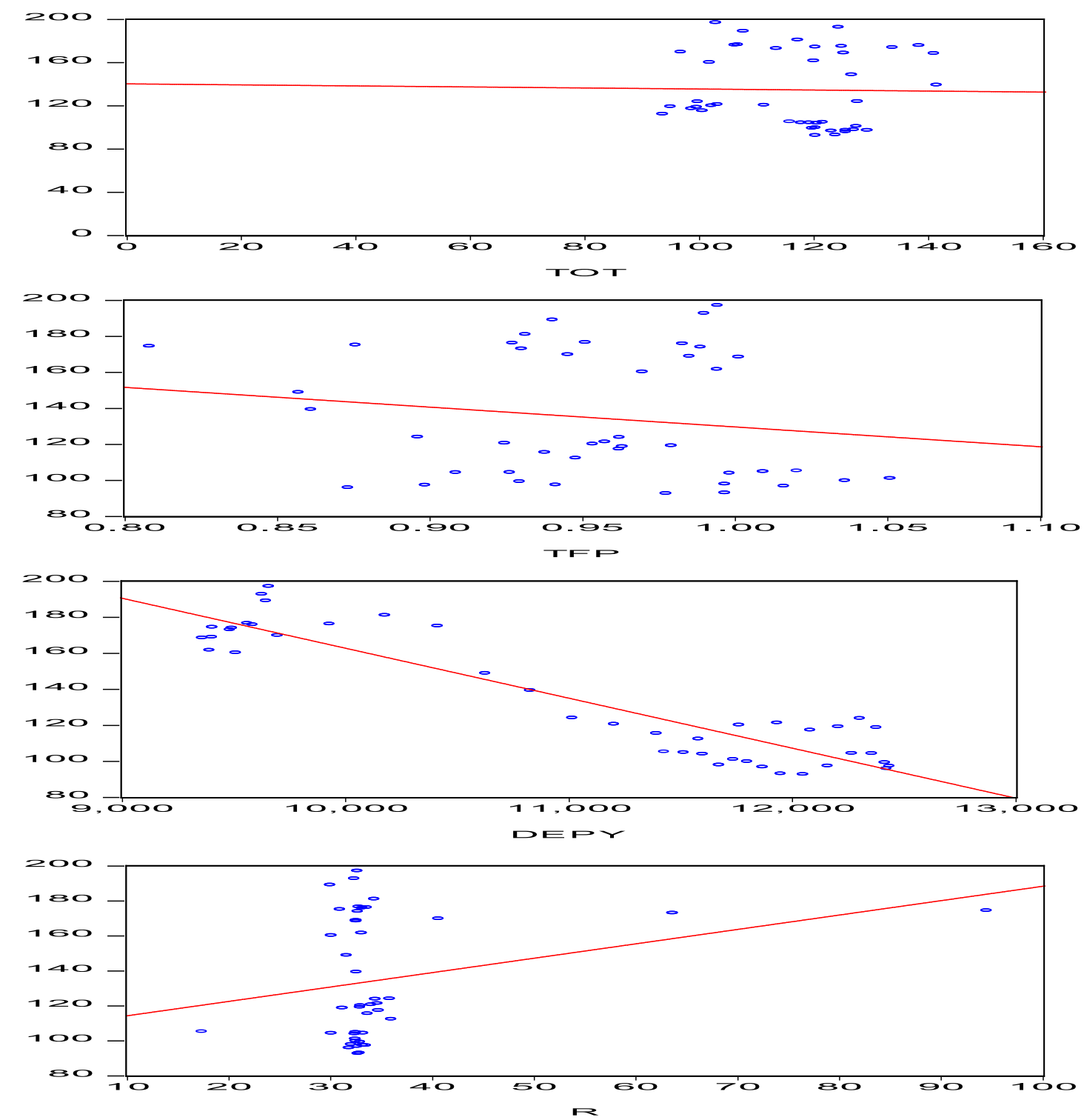
울
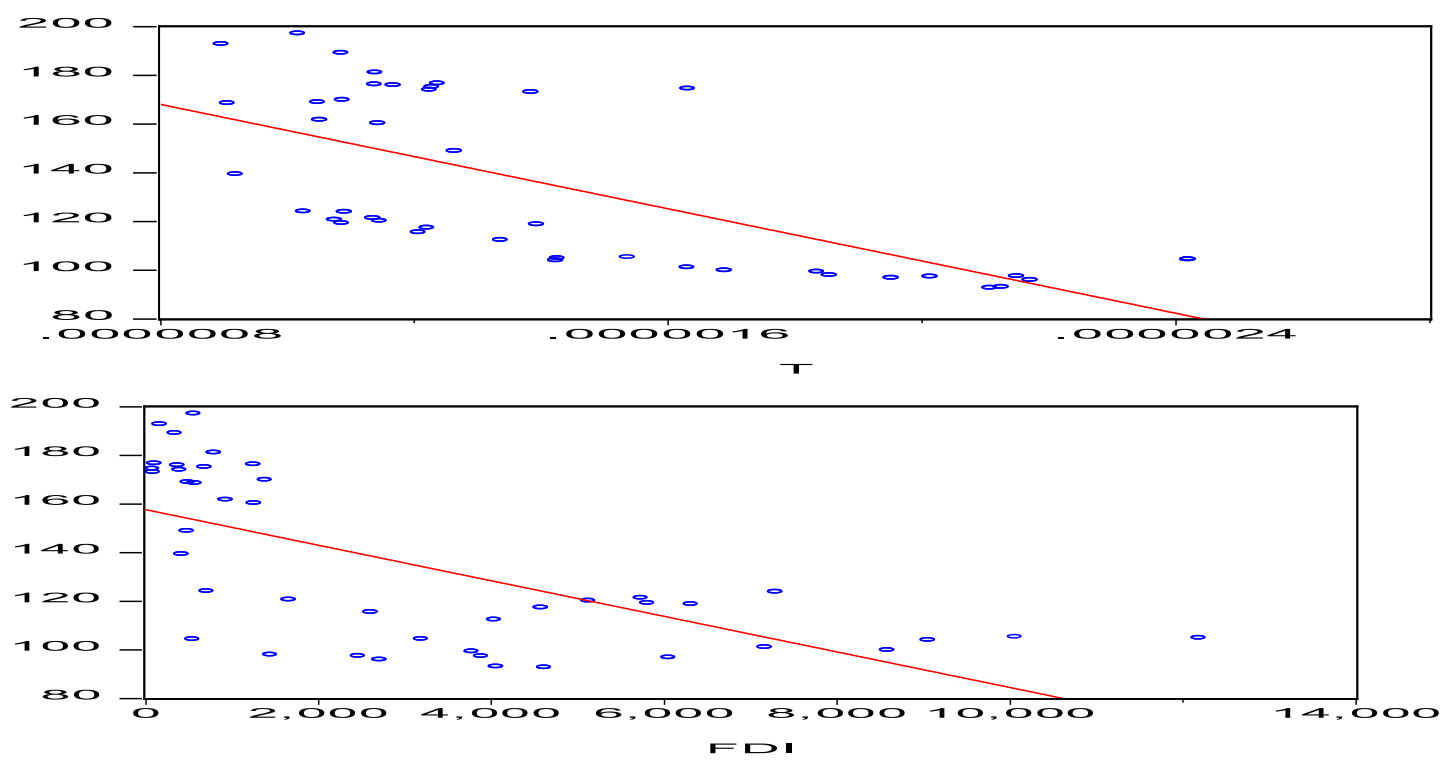

Fig.3. The relationship between exchange rates and macroeconomics fundamental in Malaysia, 1970-2012(Sources: World Development Indicators (WDI), United Nations Conference on Trade and Development (UNCTAD), United Nation Statistic Department (UNSD), Penn World Table, Asian Development Bank (ADB), International Financial Statistic (IFS). Note: REER-real effective exchange rate; TOT-terms of trade; TFP-total factor productivity; DEPY-dependency ratio of the young; R-real interest rate; T-tax revenue and FDI-foreign direct investment.)

This paper is organized as follows. The overview of the determination of equilibrium exchange rate in Malaysia is discussed in section 1. While, section 2 is a brief discussions of the theoretical framework of equilibrium exchange rates, the research design and methodology to estimate the equilibrium exchange rates in Malaysia by applying the NATREX model. The results estimations and research findings are discussed in section 3 . Section 4 is the discussion of the misalignment of currency in Malaysia and finally, section 5 will summarize the main findings and conclude with some policy implications.

\section{METHODOLOGY}

\subsection{Model (Theoretical Framework)}

The natural real exchange rates (NATREX) model developed by [17] to understand deeper the misalignment of exchange rates and its macroeconomic fundamental. NATREX model is employed in this study due to several reasons. Firstly, the NATREX model allows 
macroeconomics fundamental factors to describe the misalignment of exchange rates [13]. Secondly, this model allows exchange rates to vary over time responding to the changes in the fundamentals $[5,18]$. Lastly, this model does not require the observed real effective exchange rates (REER) and the real equilibrium exchange rate to be stationary [5-6, 13]. Generally, the NATREX model is an estimation of macro-econometric model by using time series analysis, imposing external and internal balance and solving for the equilibrium real exchange rate in the medium-term medium-run to long-run (for a comprehensive discussion see $[5,17,20]$. The model used is shown in the following Equation (1):

$\mathrm{LER}_{\mathrm{t}}=\alpha_{0}+\alpha_{1} \mathrm{LTOT}_{\mathrm{t}}+\alpha_{2} \mathrm{LTFP}_{\mathrm{t}}+\alpha_{3} \mathrm{LDEPY}_{\mathrm{t}}+\alpha_{4} \mathrm{LR}_{\mathrm{t}}+\alpha_{5} \mathrm{LT}_{\mathrm{t}}+\alpha_{6} \mathrm{LFDI}_{\mathrm{t}}+\varepsilon_{\mathrm{t}}$

whereLER $\mathrm{t}_{\mathrm{t}} \alpha$ and $\varepsilon$ denotes as real effective exchange rate, vectors of coefficients and error term respectively. Any deviation from equilibrium is reflected in the error $\left(\varepsilon_{t}\right)$ term, which includes both short-term influences and random disturbances; LTOT and LTFP are terms of trade and total factor productivity respectively; LDEPY denote dependency ratio of the young population; LR, LT and LFDI are real interest rates, tax revenue and foreign direct investment respectively. All variables are in natural logarithm. We expect a priori the expected sign of the variables as $\alpha_{1} \gtrless 0, \alpha_{2}, \alpha_{6}>0$ and $\alpha_{3}, \alpha_{4}, \alpha_{5}<0$.

According to [7, 13], the effects of terms of trade on exchange rate seems to be ambiguous depending on the relative importance of the substitution-income effects. An improvement in the terms of trade leads to the reduction in the cost of imported inputs in the production process, generating exchange rate depreciation through the substitution effect and hence $\alpha_{1}$ is expected to be positive, vice versa. Meanwhile, according to [20], the total factor productivity is able to influence domestic output $(\mathrm{Y})$ where the higher figure in the total factor productivity is due to technology growth and efficiency, and thereby increased the domestic output. The increase in total factor productivity and domestic output leads to appreciation of the real exchange rates in the long run. Further, in [20] proposed that the coefficient of the dependency ratio of the young in the model shows that the higher figure in the relative number of young (under 15) increases the consumption-to-income ratio. The increase in consumption leads to increase in borrowing from foreign country, hence causes depreciation (reduce) of the real exchange rates in the long run. Another study conducted by [16] predicted 
that the higher values in real interest rates leads to an increase in interest payment of net-debtor countries. Hence, the increase in real interest rates causes depreciation of currency. Following $[11,20]$, the tax revenue is one of the tools in explaining cost of capital function. Higher taxes would not stimulate business sector investment by increasing the user cost of capital. Hence, the aggregate investment will fall causing a depreciation of the real exchange rates in the long run. Meanwhile, another study conducted by [12] suggest that the growth in debts in the long run would cause the current account deficit resulting from the factor payments on the productive foreign direct investment which will make the currency depreciate.

The ARDL approach proposed by [14] is used to estimate the equilibrium exchange rate model. The advantage of using ARDL approach is that it is applicable regardless of the stationarity properties or irrespective of whether the regressors are purely $\mathrm{I}(0)$ or $\mathrm{I}(1)$, or mutually cointegrated. This is a useful approach that bypasses the need for pre-testing the integration order of variables, which the potential bias associated in the unit root test can be avoided. Indeed, the ARDL approach is robust for cointegration analyses with small sample study [14].

A specified 'restricted error correction model' (RECM) of the ARDL model can be used to determine the long-run relationships. For the NATREX model we can be employ RECM to examine whether $\mathrm{LTOT}_{t}, \mathrm{LTFP}_{t}, \mathrm{LDEPY}_{\mathrm{t}}, \mathrm{LR}_{\mathrm{t}}, \mathrm{LT}_{\mathrm{t}}$ and $\mathrm{LFDI}_{\mathrm{t}}$ are long-run forcing variables for REER . Therefore, Equation (1) can be rewritten as the following equation.

$\Delta \mathrm{LER}_{\mathrm{t}}=$

$\gamma_{0}+\sum_{\mathrm{i}=1}^{\mathrm{k}} \gamma_{1 \mathrm{i}} \Delta \mathrm{LER}_{\mathrm{t}-\mathrm{i}}+\sum_{\mathrm{i}=0}^{\mathrm{n}} \gamma_{2 \mathrm{i}} \Delta \mathrm{LTOT}_{\mathrm{t}-\mathrm{i}}+\sum_{\mathrm{i}=0}^{\mathrm{n}} \gamma_{3 \mathrm{i}} \Delta \mathrm{LTFP}_{\mathrm{t}-\mathrm{i}}+\sum_{\mathrm{i}=0}^{\mathrm{n}} \gamma_{4 \mathrm{i}} \Delta \mathrm{LDEPY}_{\mathrm{t}-\mathrm{i}}+$

$\sum_{\mathrm{i}=0}^{\mathrm{n}} \gamma_{5 \mathrm{i}} \Delta \mathrm{LR}_{\mathrm{t}-\mathrm{i}}+\sum_{\mathrm{i}=0}^{\mathrm{n}} \gamma_{6 \mathrm{i}} \Delta \mathrm{LT}_{\mathrm{t}-\mathrm{i}}+\sum_{\mathrm{i}=0}^{\mathrm{n}} \gamma_{7 \mathrm{i}} \Delta \mathrm{LFDI}_{\mathrm{t}-\mathrm{i}}+\beta_{1} \mathrm{LER}_{\mathrm{t}-1}+\beta_{2} \mathrm{LTOT}_{\mathrm{t}-1}+$

$\beta_{3} \mathrm{LTFP}_{\mathrm{t}-1}+\beta_{4} \mathrm{LDEPY}_{\mathrm{t}-1}+\beta_{5} \mathrm{LR}_{\mathrm{t}-1}+\beta_{6} \mathrm{LT}_{\mathrm{t}-1}+\beta_{7} \mathrm{LFDI}_{\mathrm{t}-1}+\mathrm{v}_{\mathrm{t}}$

wherev is disturbance term. By using the F-test, the null hypothesis of non-existence of the long-run relationship for NATREX model is tested onH $\mathrm{o}_{\mathrm{o}} \beta_{1}=\beta_{2}=\beta_{3}=\beta_{4}=\beta_{5}=\beta_{6}=$ $\beta_{7}=0$ against $\mathrm{H}_{\mathrm{a}}: \beta_{1} \neq \beta_{2} \neq \beta_{3} \neq \beta_{4} \neq \beta_{5} \neq \beta_{6} \neq \beta_{7} \neq 0$. According to [14], the bounds F-test must be valid by ensuring that there is no serial correlation. In this study, we employ the LM statistics for testing the hypothesis of no serial correlation. Meanwhile, the 
Schwartz-Bayesian information criterion (SBC) is used to determine the optimal lag length, $\mathrm{k}$ and $\mathrm{n}$ above.

From Equation (2), the long run equation presented as in Equation (1) can be derived when we have $\alpha_{0}=\frac{\gamma_{0}}{1-\sum \gamma_{1 \mathrm{i}}}, \alpha_{1}=\frac{\sum \gamma_{2 \mathrm{i}}}{1-\sum \gamma_{1 \mathrm{i}}}, \alpha_{2}=\frac{\sum \gamma_{3 \mathrm{i}}}{1-\sum \gamma_{1 \mathrm{i}}}, \alpha_{3}=\frac{\sum \gamma_{4 \mathrm{i}}}{1-\sum \gamma_{1 \mathrm{i}}}, \alpha_{4}=\frac{\sum \gamma_{5 \mathrm{i}}}{1-\sum \gamma_{1 \mathrm{i}}}, \alpha_{5}=\frac{\sum \gamma_{6 \mathrm{i}}}{1-\sum \gamma_{1 \mathrm{i}}}$ and $\alpha_{6}=\frac{\sum \gamma_{7 i}}{1-\sum \gamma_{1 i}}$.In order to estimate the short-run coefficients and to estimate the speed of adjustment, the following ARDL-Restricted ECM (RECM) equation can be specified by rewriting Equation (2) as the following equation:

$\Delta \mathrm{LER}_{\mathrm{t}}=$ $\delta_{0}+\sum_{\mathrm{i}=1}^{\mathrm{k}} \delta_{1 \mathrm{i}} \Delta \mathrm{LER}_{\mathrm{t}-\mathrm{i}}+\sum_{\mathrm{i}=0}^{\mathrm{n}} \delta_{2 \mathrm{i}} \Delta \mathrm{LTOT}_{\mathrm{t}-\mathrm{i}}+\sum_{\mathrm{i}=0}^{\mathrm{n}} \delta_{3 \mathrm{i}} \Delta \mathrm{LTFP}_{\mathrm{t}-\mathrm{i}}+\sum_{\mathrm{i}=0}^{\mathrm{n}} \delta_{4 \mathrm{i}} \mathrm{LDEPY}_{\mathrm{t}-\mathrm{i}}+$

$\sum_{\mathrm{i}=0}^{\mathrm{n}} \delta_{5 \mathrm{i}} \Delta \mathrm{LR}_{\mathrm{t}-\mathrm{i}}+\sum_{\mathrm{i}=0}^{\mathrm{n}} \delta_{6 \mathrm{i}} \Delta \mathrm{LT}_{\mathrm{t}-\mathrm{i}}+\sum_{\mathrm{i}=0}^{\mathrm{n}} \delta_{7 \mathrm{i}} \Delta \mathrm{LFDI}_{\mathrm{t}-\mathrm{i}}+\lambda \mathrm{EC}_{\mathrm{t}-1}+\mathrm{w}_{\mathrm{t}}$

where $\mathrm{EC}_{\mathrm{t}-1}$ is the residuals lagged one period from the long-run Equation (1) between the dependent and independent variables in level. The significance and the negative sign of the error correction term $\left(\mathrm{EC}_{\mathrm{t}-1}\right)$ indicates co-integration (or long run relationships), and $\lambda$ measure the speed of adjustment and the deviation from equilibrium. However, the negative value for $\lambda$ suggests that the model is stable and any deviation from equilibrium will be corrected in the long-run. According to [14], the existence of an error correction model implies co-integration of the variables. Therefore, the long-run relationship is valid and free from spurious regression problem.

\subsection{Data}

This study uses annual data for Malaysia starting from 1970 until 2012. The REER is the weighted average of a country's currency relative to the trading partners of Malaysia. An increase in the index indicates appreciation of the home currency against the basket of currencies of trading partners. The TOT is the ratio of domestic export unit value (export price in US Dollars) to import value (import price in US Dollars) as a proportion of the equivalent effective foreign ratio. Meanwhile, TFP and DEPY are total factor productivity constant national prices $(2005=100)$ and dependency ratio of the young as population under 15 deflated by working population respectively. $\mathrm{R}$ is the real lending interest rate adjusted for inflation as measured by the GDP deflator. T is tax revenue divided by nominal GDP. Whilst, FDI is ratio of foreign direct investment net inflows to GDP. 
All the data series were obtained from various sources such as the International Monetary

Fund's International Financial Statistics (IMF/IFS), United Nations Statistical Division (UNSD), United Nations Conference on Trade and Development (UNCTAD), Asian Development Bank (ADB), Worldbank's World Development Indicators (WDI), Penn World Table (PWT) and www.bruegel.org.

\section{RESULTS AND DISCUSSION}

\subsection{Results of Unit Root Test}

The discussions begin with the analysis of unit root test using Kwiatkowski-Phillips-Schmidt-Shin (KPSS) approach. The purpose of employing the unit root tests is to examine the existence of stochastic non-stationary in the series.

Table 1 is the empirical results of the unit root tests. All the variables in this study such as LER, LTOT, LTFP, LDEPY, LR, LT and LFDI are tested based on "no trend and constant", "trend and constant". Based on Table 1, the outcomes from the unit root tests of KPSS clearly indicates that all variables are mixture of $\mathrm{I}(0)$ and $\mathrm{I}(1)$, and none is $\mathrm{I}(2)$. Therefore, the ARDL modeling approach can be used in the estimation of NATREX model.

Table 1. Results of KPSS unit root test

\begin{tabular}{ccccc}
\hline & \multicolumn{3}{c}{ KPSS Unit Root Tests, T-Statistics } \\
Var. & \multicolumn{2}{c}{ Series in Level } & \multicolumn{2}{c}{ Series in 1st Diff. } \\
& No Trend & Trend & No Trend & Trend \\
\hline LER $_{\mathrm{t}}$ & $0.75 * * *(5)$ & $0.120 *(4)$ & $0.113(4)$ & $0.100(4)$ \\
$\mathrm{LTOT}_{\mathrm{t}}$ & $0.107(3)$ & $0.102(3)$ & $0.041 * *(2)$ & $0.04 * *(2)$ \\
$\mathrm{LTFP}_{\mathrm{t}}$ & $0.231(4)$ & $0.112(4)$ & $0.124(2)$ & $0.110(2)$ \\
$\mathrm{LDEPY}_{\mathrm{t}}$ & $0.664 * *(5)$ & $0.118(10)$ & $0.290(5)$ & $0.12(10)$ \\
$\mathrm{LR}_{\mathrm{t}}$ & $0.492 * *(2)$ & $0.107(1)$ & $0.193(1)$ & $0.171(1)$ \\
$\mathrm{LT}_{\mathrm{t}}$ & $0.500^{* *(5)}$ & $0.116(4)$ & $0.147(3)$ & $0.114(3)$ \\
$\mathrm{LFDI}_{\mathrm{t}}$ & $0.74 * * *(5)$ & $0.116(4)$ & $0.085(4)$ & $0.052 *(4)$ \\
\hline
\end{tabular}

Note: The value in parentheses (.) represent the automatic bandwidth selected based on Newey-West method using Bartlett kernel. The ***,** and * indicate the statistically 
significant level at 1\%,5\% and 10\%. LER-real effective exchange rate, LTOT-terms of trade, LTFP-total factor productivity, LDEPY-dependency ratio of the young, LR-real interest rate, LT-tax revenue and LFDI-foreign direct investment. All variable are in logarithm.

\subsection{Results of Cointegration Test}

The next analysis is to determine the existence of a long-term cointegrating relationship between the exchange rates, and the macroeconomics variables in Malaysia by using the ARDL bound test. Table 2 presents the empirical result of bound test for NATREX model and the lag length for this regression were automatically selected based on Schwarz Bayesian Criterion (SBC).

Table 2. Results of cointegration bounds test

\begin{tabular}{crcc}
\hline F-Statistics & & Lower Bound & Upper Bound \\
\hline F-Statistics & $90 \%$ & 2.141 & 3.250 \\
{$[14]$} & $95 \%$ & 2.476 & 3.646 \\
Computed F-Statistic & & $\mathrm{F}=4.2809^{* *}$ \\
\hline
\end{tabular}

Note: $* *$ and $*$ indicate the statistically significant level at $5 \%$ and $10 \%$. The critical values are obtained from [14].

The result of bound test shows that the F-statistic for NATREX model fall above the upper bound critical value at 5\% significance level. This result suggest that cointegration exists among the variables in the model under investigation.

\subsection{Diagnostic Tests}

The statistical validity of the ARDL model has been ascertained by a battery of tests, which includes serial correlation LM test, ARCH test for heteroscedasticity and Jarque-Bera normality test on the residual. Generally, the diagnostic tests for NATREX model in Malaysia produce good results. Table 3clearly indicates that the model is free from serial correlation and heteroscedasticity, and the residual is normally distributed.

Table 3. Results of diagnostic tests for ARDL 


\begin{tabular}{cc}
\hline Diagnostic Checking & P-Value \\
\hline Serial Correlation & 0.770 \\
Normality & 0.873 \\
Heteroscedasticity & 0.151 \\
\hline
\end{tabular}

Note:ARDL(2,2,0,0,0,1,0) was automatic selected on the basis of SBC.

\subsection{Estimates of Long-Run Model}

Table 4 shows the long run coefficients of the ARDL model with estimated lag orders for this model as ARDL(2,2,0,0,0,1,0). The optimal lag lengthwas automatically selected on the basis of SBC. The results clearly indicates that LTOT,LDEPY and LFDI are statistically significant at least at the $5 \%$ level. In the long run, the model explains that the higher level of terms of trade, dependency ratio of the young population and foreign direct investment could lead to depreciation in the exchange rates in Malaysia. Following [13, 20], the negative impact of terms of trade on exchange rates explain that the improvement in terms of trade reduces demand for non-tradable, decreases the users cost of capital (consumption effect) and stimulate investment demand in the non-tradable component (investment effect). Therefore, the relative price of non-tradable to imports will decrease as well as real exchange rates (depreciation) due to the consumption effect which are greater than investment effect. Meanwhile, the negative impact of dependency ratio of the young on exchange rates explains that the higher in the relative number of young (under 15) increased the consumption-to-income ratio. The increasing consumption leads to increase in borrowing from foreign country, hence causing depreciation (reduce) of the real exchange rates in the long run. Besides that, the negative impact of foreign direct investment on exchange rates in Malaysia in the model is not compatible with the explanation of theoretical predictions. Nevertheless, this result is consistent with a study conducted by [9]. The result in their study showed that the foreign direct investment has the opposite sign than was expected for Slovakia. The possible explanation of this result is due to high volatility of foreign direct investmentduring the Russian and Asian financial crises 1997/1998 that creates uncertainty among foreign investors thus influencing the stability in exchange rates, hence the exchange 
rates tend to be depreciated.

Table 4. Results of long-run coefficient

\begin{tabular}{ccccc}
\hline Variables & Exp. Sign & Coeff. & S.E. & T-Stat \\
\hline LTOT & $+/-$ & -0.913 & 0.233 & $-3.922 * * *$ \\
LTFP & + & -0.257 & 0.418 & -0.615 \\
LDEPY & - & -1.735 & 0.275 & $-6.318^{* * *}$ \\
LR & - & -0.073 & 0.111 & -0.657 \\
LT & - & -0.095 & 0.075 & -1.257 \\
LFDI & + & -0.047 & 0.021 & $-2.279 * *$ \\
C & & 24.662 & 3.757 & $6.564 * * *$ \\
\hline
\end{tabular}

Notes: Asterisk $* * *, * *$ and $*$ denotes statistically significance at $1 \%, 5 \%$ and $10 \%$, respectively. LTOT-terms of trade, LTFP-total factor productivity, LDEPY-dependency ratio of the young, LR-real interest rate, LT-tax revenue and LFDI-foreign direct investment. All variable are in logarithm.

\subsection{Estimates of Error Correction Model (ECM)}

According to [8], the error correction model (ECM) is the short-run model with long-run information. If the ECM is negative and significant, therefore these imply that independent variable Granger cause dependent variable and are cointegrated. Based on Table 5, the error correction term in the model shows that it is significant at $1 \%$ level. It also carries the expected negative sign. This indicates that the model is stable and any deviation from equilibrium will be corrected in the long run [10]. The coefficient of the error correction term implies the speed of adjustment. Based on the result, the coefficient of the error correction term for NATREX model is 0.50 . This indicates that $50 \%$ of the previous year's shocks adjust back to long-term equilibrium in the current year. This result also provides further evidence of the existence of a stable long-run relationships among the variables in the exchange rates model.

Table 5. Results of short-run coefficient and error correction model (ECM) 


\begin{tabular}{cccc}
\hline Variables & Coeff. & S.E. & T-Stat \\
\hline$\Delta$ LER $(-1)$ & 0.357 & 0.137 & $2.616^{* *}$ \\
$\Delta$ LTOT & -0.225 & 0.081 & $-2.786^{* * *}$ \\
$\Delta$ LTOT $(-1)$ & 0.262 & 0.090 & $2.920^{* * *}$ \\
$\Delta$ LTFP & -0.129 & 0.232 & -0.557 \\
$\Delta$ LDEPY & -0.871 & 0.270 & $-3.230^{* * *}$ \\
$\Delta$ LR & -0.037 & 0.056 & -0.654 \\
$\Delta$ LT & -0.222 & 0.048 & $-4.595^{* * *}$ \\
$\Delta$ LFDI & -0.024 & 0.011 & $-2.138^{* *}$ \\
$\Delta$ C & 12.379 & 3.240 & $3.821^{* * *}$ \\
ECM(-1) & -0.502 & 0.140 & $-3.586^{* * *}$ \\
\hline
\end{tabular}

Notes: Asterisk $* * *, * *$ and $*$ denotes statistically significance at $1 \%, 5 \%$ and $10 \%$ respectively. LER-real effective exchange rate, LTOT-terms of trade, LTFP-total factor productivity, LDEPY-dependency ratio of the young, LR-real interest rate, LT-tax revenue and LFDI-foreign direct investment. All variable are in logarithm.

Another characteristic of the ARDL model is that the dependent variables not only can be explained by the independent variables in the model, but it can also be explained by the value of itself in the past. Based on Table 5, the result for short-run relationship in the model shows that the lagged one period of the exchange rates is positive and statistically significant at $1 \%$ level. This explains that a $1 \%$ increase (appreciation) in past one year exchange rates lead to appreciation in exchange rate at $0.36 \%$ in the current year.

\subsection{Misalignment of Exchange Rates in Malaysia}

This section is going to present the misalignment of Ringgit against US dollar. Generally, the misalignment of exchange rates is the deviation of the actual exchange rate from an estimate of its equilibrium values [9]. Table 6 shows the percentage of the misalignment in exchange rate, and Fig. shows the plot of residuals and two standard error bands. The result reveals that the misalignment of exchange rates is quite small and stable in Malaysia during 1983 to 2012. In addition, the result shows that Malaysia had experienced a shock or spike of exchange rates in 1995 due to an excessive foreign exchange speculation. However, the Malaysian 
government has intervened to offset the significant upward pressure on the currency.

Table 6. Misalignment of exchange rates in Malaysia, 1983-2012

\begin{tabular}{cccc}
\hline Year & $\%$ & Year & $\%$ \\
\hline 1983 & 0.01 & 1998 & -0.05 \\
1984 & 0.03 & 1999 & 0.05 \\
1985 & 0.05 & 2000 & 0.02 \\
1986 & -0.05 & 2001 & 0.08 \\
1987 & -0.01 & 2002 & 0.02 \\
1988 & -0.03 & 2003 & -0.06 \\
1989 & 0.04 & 2004 & -0.03 \\
1990 & -0.02 & 2005 & 0.01 \\
1991 & -0.04 & 2006 & 0.00 \\
1992 & -0.00 & 2007 & -0.01 \\
1993 & -0.04 & 2008 & 0.01 \\
1994 & -0.02 & 2009 & -0.04 \\
1995 & 0.84 & 2010 & 0.01 \\
1996 & 0.05 & 2011 & 0.01 \\
1997 & 0.02 & 2012 & -0.02 \\
\hline
\end{tabular}

Notes: Figures are exchange rate misalignments in percentage (\%). A misalignment is the residual between actual and fitted values of exchange rate. Positive (negative) value for residual denotes an undervaluation (overvaluation).

Plot of Residuals and Two Standard Error Bands

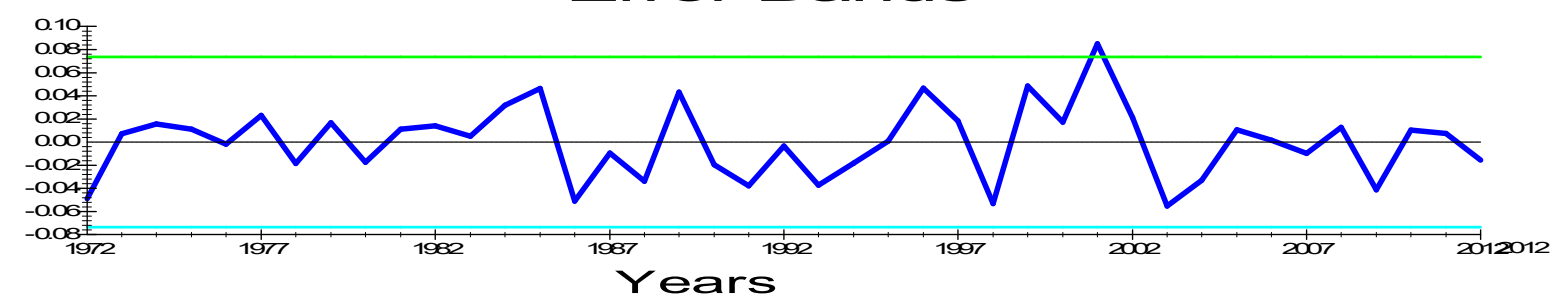

Fig.4. Residuals and two standard error bands for NATREX model(Notes: The movements of the residuals above zero (positive value) are associated with undervalued exchange rate, whilst below zero (negative value) are associated with overvalued exchange rate.)

On the other hand, our results further suggest that the NATREX model fit the data very 
closely throughout the period. Fig. shows that the model tracked the actual exchange rate well and managed to get a considerable number of turning points. This results is similar to the study conducted by [1-2].

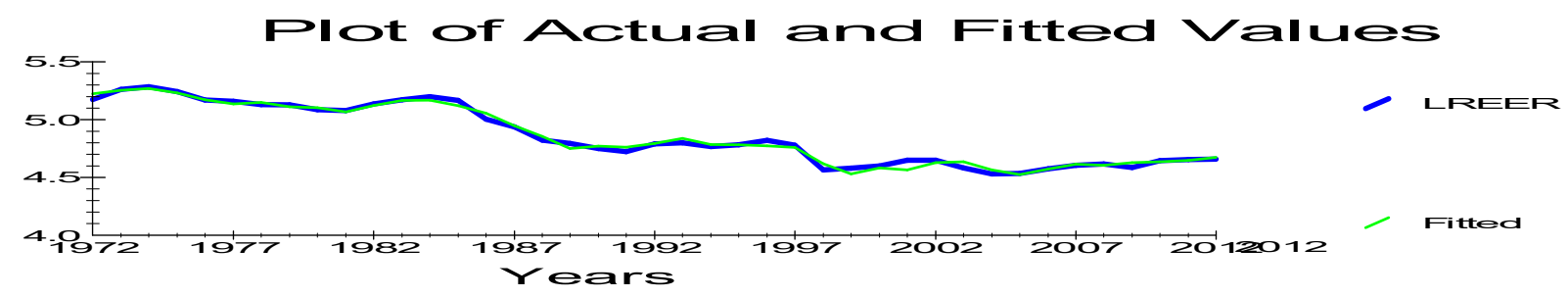

Fig.5. Actual values and fitted values of NATREX model in Malaysia(Note: Malaysia (Malaysian Ringgit, MYR, RM))

\section{CONCLUSION}

This study has investigated the exchange rates behavior by estimating equilibrium exchange rates in Malaysia. In order to understand deeper the misalignment of exchange rates and its macroeconomic fundamental in Malaysia, the NATREX model is used. By adopting the ARDL modeling approach, this study is able to make correct analyses of the short-run and long-run relationships (cointegration) between exchange rates and its macroeconomic fundamental. Hence, we find that the terms of trade, dependency ratio of the young and foreign direct investment are important factors influencing exchange rates in Malaysia.

The investigation of the misalignment of exchange rates was done by examining the difference (residuals) between the actual real exchange rates and the estimated exchange rate calculated from the NATREX model. The result shows that the misalignment of exchange rates for Ringgit Malaysia is quite small. The overvaluation of Ringgit Malaysia in NATREX model lies in the range of $0.01-0.06 \%$, whilst the undervaluation lies in the range of 0.01-0.84\%. Generally, the misalignment of exchange rates is stable in Malaysia during 1983 to 2012 except in 1995 (see Table 6 and Fig.).

This paper also showed that the macroeconomics fundamental factors using NATREX model are also important variables in determining exchange rates behaviors, instead of price based factors using PPP/LOP models (see Fig. and Fig.).

The policy implications of this study are suggested as follow. Firstly, the long-run and 
short-run relationship between exchange rates and its macroeconomic variables (terms of trade, dependency ratio of the young, and foreign direct investment) in NATREX model shows that these variables are important determinants of the exchange rates. This evidence suggests that the exchange rates in Malaysia are driven by its macroeconomic variables. Secondly, the policy makers should take into account the macroeconomic indicators in order to achieve economic goals for Malaysia. In this paper, the terms of trade, dependency ratio of the young and foreign direct investment play important roles to achieve the goals. Therefore, policy makers in Malaysia can monitor whether the real exchange rates would be undervalued or overvalued in the future by tracking these macroeconomics variables.

\section{REFERENCES}

[1] Chin L. The monetary approach to exchange rate determination in five ASEAN countries. Selangor: Universiti Putra Malaysia, 2005

[2] Chin L, Azali M. Exchange rate misalignments in ASEAN-5 countries. Labuan Bulletin of International Business and Finance, 2005, 3:11-31

[3] Corsetti G, Pesenti P, Roubini N. What caused the Asian currency and financial crisis? Japan and the World Economy, 1999, 11(3):305-373

[4] Daniel J P, VanHoose D D. International monetary and financial economics. Ohio: South-Western College Publishing, 2005

[5] Driver R L, Westaway P F. Concepts of equilibrium exchange rates. Bank of England Publications Working Paper No. 248, 2004, pp. 1-62

[6] Edwards S, Savastano M. Exchange rates in emerging economics: What do we know? What do we need to know? National Bureau of Economic Research Working Paper No. 7228, 1999, pp. 1-74

[7] Elbadawi I A, Soto R. Capital flows and long-term equilibrium real exchange rates in Chile. Policy Research Working Paper No. 1306, 1994, pp. 1-40

[8] Engle R F, Granger C W J. Co-integration and error correction: Representation, estimation, and testing. Econometrica, 1987, 55(2):251-276

[9] Frait J, Komarek L, Melecký M. The real exchange rate misalignment in the five central 
European countries. Warwick Economic Research Papers No. 739, 2004, pp. 1-34

[10] Habibullah M S, Din B H, Abdullah H. Border effects: The cases for states of northen Malaysia and provinces of southern Thailand. Journal of International Economic Review, 2012, 5(1):15-27

[11] He X, Qin D. Aggregate investment in people's Republic of China: Some empirical evidence. Asian Development Review, 2004, 21(1):99-117

[12] Melecky M, Komarek L. The behavioral equilibrium exchange rate of the Czech Koruna. Transition Studies Review, 2007, 14(1):105-121

[13] Naseem N A M, Hui B T, Hamizah M S. Exchange rate misalignment, volatility and import flows in Malaysia. International Journal of Economics and Management, 2009, 3(1):130-150

[14] Pesaran M H, Shin Y, Smith R J. Bounds testing approaches to the analysis of level relationships. Journal of Applied Econometrics, 2001, 16(3):289-326

[15] Rodrik D. The real exchange rate and economic growth. Brookings Papers on Economic Activity, 2008, 2:365-412

[16] Sahminan S. Estimating equilibrium real exchange rates of the Rupiah.Working Paper WP/08/2005, Jakarta: Bank Indonesia, 2005

[17] Stein J L. The fundamental determinants of the real exchange rate of the U.S. Dollar relative to other G-7 currencies. IMF Working Paper No. 95/81, 1995, pp. 1-46

[18] Stein J, Lim G. Introduction to exchange rates in Europe and Australia: Fundamental determinants, adjustment and policy implications. Australia Economic Papers, 2002, $41: 329-341$

[19] Villavicencio A L. Real equilibrium exchange rate: A panel data approach for advanced and emerging economies. Economie Internationale, 2006, 108(4):59-81

[20] You K, Sarantis N. Structural breaks and the equilibrium real effective exchange rate of China: A NATREX approach. China Economic Review, 2012, 23(4):1146-1163

\section{How to cite this article:}

Shukri J M, Habibullah M S, Yusop Z, Chin L. The study of exchange rates behavior in 
Malaysia by using natrex model. J. Fundam. Appl. Sci., 2017, 9(3S), 697-715 